\title{
DIATOMS FROM THE COLOMBIAN AMAZON: SOME SPECIES OF THE GENUS Eunotia (BACILLARIOPHYCEAE)
}

\author{
Silvia Estela SALA ${ }^{1}$, Santiago R. DUQUE ${ }^{2}$, Marcela NÚ̃̃EZ-AVELLANEDA ${ }^{3}$, \\ Anabel Alejandra LAMARO ${ }^{1}$
}

\begin{abstract}
This research was carried out in three of the most important basins of the Colombian Amazon (Upper Solimões, Iça and Japurá Rivers). The creeks and lakes that were studied contain abundant diatom species, particularly those of the genus Eunotia. Ten species are described; five of them are registered for the first time in the Amazon basin, and six in all of Colombia. All taxa were photographed with scanning electron microscopy. Fine valve morphology of E. anamargariate, E. pseudoindica, E. triodon, and E. zydodon var. compacta is described for the first time.
\end{abstract}

Key-words: Diatoms, Eunotia, distribution, ecology, Colombian Amazon Basin.

Diatomáceas da Amazônia Colombiana II: Algumas Espécies do Gênero Eunotia (Bacillariophyceae).

RESUMO - O trabalho realizou-se nas três bacias mais importantes da Amazônia Colombiana (Alto Solimões, Içá e Japurá). Os igarapés e lagos estudados apresentam alta riqueza de diatomáceas, principalmente do gênero Eunotia. Foram descritas 10 espécies e, pela primeira vez, a morfologia das valvas de E. anamargaritae, E. pseudoindica, E. triodon e E. zydodon var. compacta, foram descritas ao microscópio eletrônico. Dentre as espécies de Eunotia, encontradas no presente estudo, seis são primeiras citações para a Colômbia e cinco para a região amazônica.

Palavras-chave: Diatomáceas, Eunotia, distribuição, ecología, Amazônia Colombiana.

\section{Introduction}

Diatom species from temperate regions of South America are mostly cosmopolitan or characteristic of those climatic zones of the world. However, South American tropical habitats seem to have a particular flora. This is evident in classic papers (Hustedt, 1965; Schmidt et al., 1874-1959) and in recent ones (Reichardt, 1995; Metzeltin \& Lange-Bertalot, 1998). Among tropical environments, Amazonia is very interesting due to high biodiversity. Nevertheless, there are just a few taxonomic studies of diatoms from this region (SouzaMosimann et al., 1997 in Brazil; Oliveira \& Steinitz-Kannan, 1992 in Ecuador; and Sala et al., 1999, 2002 in Colombia). There are also some references in phytoplankton papers (Uherkovich, 1976; Uherkovich \& Schmidt, 1974; Uherkovich \& Rai, 1979; Uherkovich \& Franken, 1980; Duque, 1998) and in the morphologic and taxonomic work of Metzeltin \& Lange-Bertalot (1998).

As a result of a preliminary study carried out in the Colombian Amazon,

\footnotetext{
${ }^{1}$ Departamento Científico Ficología. Facultad de Ciencias Naturales y Museo. Paseo del Bosque s/n .1900. La Plata. Argentina. E-mail sesala@museo.fcnym.unlp.edu.ar

${ }^{2}$ Instituto Amazónico de Investigaciones - IMANI. Universidad Nacional de Colombia. Apartado Aéreo 215. Leticia, Colombia.

${ }^{3}$ Instituto Amazónico de Investigaciones Científicas SINCHI. Avenida Vásquez Cobo entre calles 15 y 16 . Leticia, Colombia.
} 
103 diatom taxa were identified. Some of these species could be accurately determined, but 35 could not be associated to any described taxa in the literature, suggesting that there is a rich unknown diatom flora in these habitats. The aquatic waterbodies sampled have conditions of low to moderate trophic level, $\mathrm{pH}$ between 4.6 - 7.4, low transparency (0.5-1.67 $\mathrm{m}$ of Secchi disc), and high temperature (26-32 $\left.{ }^{\circ} \mathrm{C}\right)$. In Amazonian aquatic environments conductivity is low, especially in Colombia in some of the study sites like Lake Taraira were registered values of $5 \mu \mathrm{S} \mathrm{cm}{ }^{-1}$ due to the influence of the Guayana Shield (Furch \& Klinge, 1978, 1982; Gibbs, 1970; Duque et al., 1997),

One of the best-represented genera in the study area is Eunotia with 27 species, near $30 \%$ of the studied taxa. Eunotia is a large genus that comprises around 200 species (Van Landingham, 1969). Despite its abundance in freshwater habitats (especially acid waters), there are few studies about species' valve structure. This is evident since in the bibliographic compilation on fine structure of the diatom taxa of Gaul et al. (1993) there are references for about 50 species. Round et al. (1990) pointed out that a revision at species level is necessary. In addition, there are difficulties of species identification due to the great variability of valve outline and dimensions throughout the life cycle (Mayama, 1992; Mayama \& Kobayasi, 1991).

The genus has a world-wide distribution, but numerous species are restricted to tropical areas. A modern and exhaustive revision of the group was done by Krammer \& LangeBertalot (1991), but these authors based their research principally on materials collected in European temperate environments. The first comprehensive analysis of tropical species using electron microscopy showed the species richness of the genus in South American tropical environments and found that $20 \%$ of the analyzed taxa belong to Eunotia (Metzeltin \& Lange-Bertalot, 1998). On the basis of the studies done with both light and electron microscopy they described nearly 40 new species of the genus. Although they analyzed materials from Amazonia there are no references about the Colombian portion of the basin.

The aim of this paper is to the contribute to knowledge of the diatom flora and the tropical species of Eunotia from the Colombian Amazon through an analysis of the fine morphology of some taxa collected in this area.

\section{Materials and Methods}

Samples for the analysis were collected during 1993 and 1994 in seven different water bodies in the Colombian Amazon basin: Tarapoto Lake, Arara Creek, Resaca Lake, Tunda Lake, belong to Solimões River (Amazon River), Quinina Lake to Iça River (Putumayo) and Taraira I Lake to Japurá River (Caquetá). General information about the study area is given in Sala et al. (2002).

Horizontal and vertical tows were made with a plankton net (mesh 
size $=24 \mu \mathrm{m})$ at different depths of the photic zone, and benthic diatoms were sampled by squeezing macrophytes. At each sampling site physical and chemical parameters: $\mathrm{pH}$, dissolved oxygen, temperature, water transparency (Secchi disc) and conductivity were registered (Tab. 1).

Samples were fixed with 6-8 \% formaline and were treated to eliminate organic matter following the method described in Hasle \& Fryxell (1970) and/or in a muffle furnace at $500{ }^{\circ} \mathrm{C}$ during 10 minutes. Samples for light microscopy (LM) were mounted in Hyrax and for scanning electron microscopy (SEM) were mounted on glass stubs and then metalized with gold-palladium. Observations were carried out with a Wild M20 LM and a Jeol TM 100 SEM.

Materials are deposited in the Colección Ficoteca Amazónica at the Universidad Nacional de Colombia (Tab. 1). Unclean and cleaned subsamples and permanent slides are deposited at the Herbario of the Departamento Científico Ficología, Museo de Ciencias Naturales de La Plata.

\section{Results}

Eunotia anamargaritae (Hustedt) Metzeltin \& Lange-Bertalot Figs.1 E-G

Metzeltin \& Lange-Bertalot 1998: 51, pl. 37, fig. 9.

Bas.: Eunotia zygodon var. elongata Hustedt, 1913 in Schmidt et al. 1874-1959: Atlas Diat. Kund. Reis. pl. 287, fig. 14 .

Valves isopolar with the ventral margin slightly concave and the dor- sal one with two undulations; ends not differentiated from the rest of the valve. Striae uniseriate, parallel or slightly radial alongside the valve face and strongly radial at the ends. Areolae small, not visible with LM. Raphe indistinguishable at LM; with SEM it is possible to see that it is well developed on the mantle, oblique at valve face without dilated endings. Girdle bands with several rows of poroids. Dimensions: length: 178-228 $\mu \mathrm{m}$; breadth: $17-20 \mu \mathrm{m}$; striae in 10 $\mu \mathrm{m}$ : 14-17; areolae in $10 \mu \mathrm{m}: 20$.

Studied Material: samples 163, 312 .

Ecology: in the study area the species was collected in habitats with pH 4.8-6.6, conductivity: 10-106 $\mu \mathrm{S} . \mathrm{cm}^{-1}$ and transparency: $0.60-0.65$ $\mathrm{m}$. The range of variability of environmental parameters is rather wider than that mentioned in Sala et al. (2002).

Distribution: Demerara River, Guyana (Krammer \& Lange-Bertalot, 1991); Brazilian Amazon (Metzeltin \& Lange-Bertalot, 1998) and Colombian Amazon (Sala et al. 2002).

Observations: In the literature this species was described only with LM, here we give details of fine valve morphology.

\section{Eunotia camelus Ehrenberg}

Figs. 1 A-D

Ehrenberg 1841 (1843): 125 (413), 2/1, fig. 1.

Valves slightly curved, dorsal margin with two to four undulations and ventral margin slightly concave; ends of the valve subrostrate, dorsally bent. Striae slightly radial, parallel at 


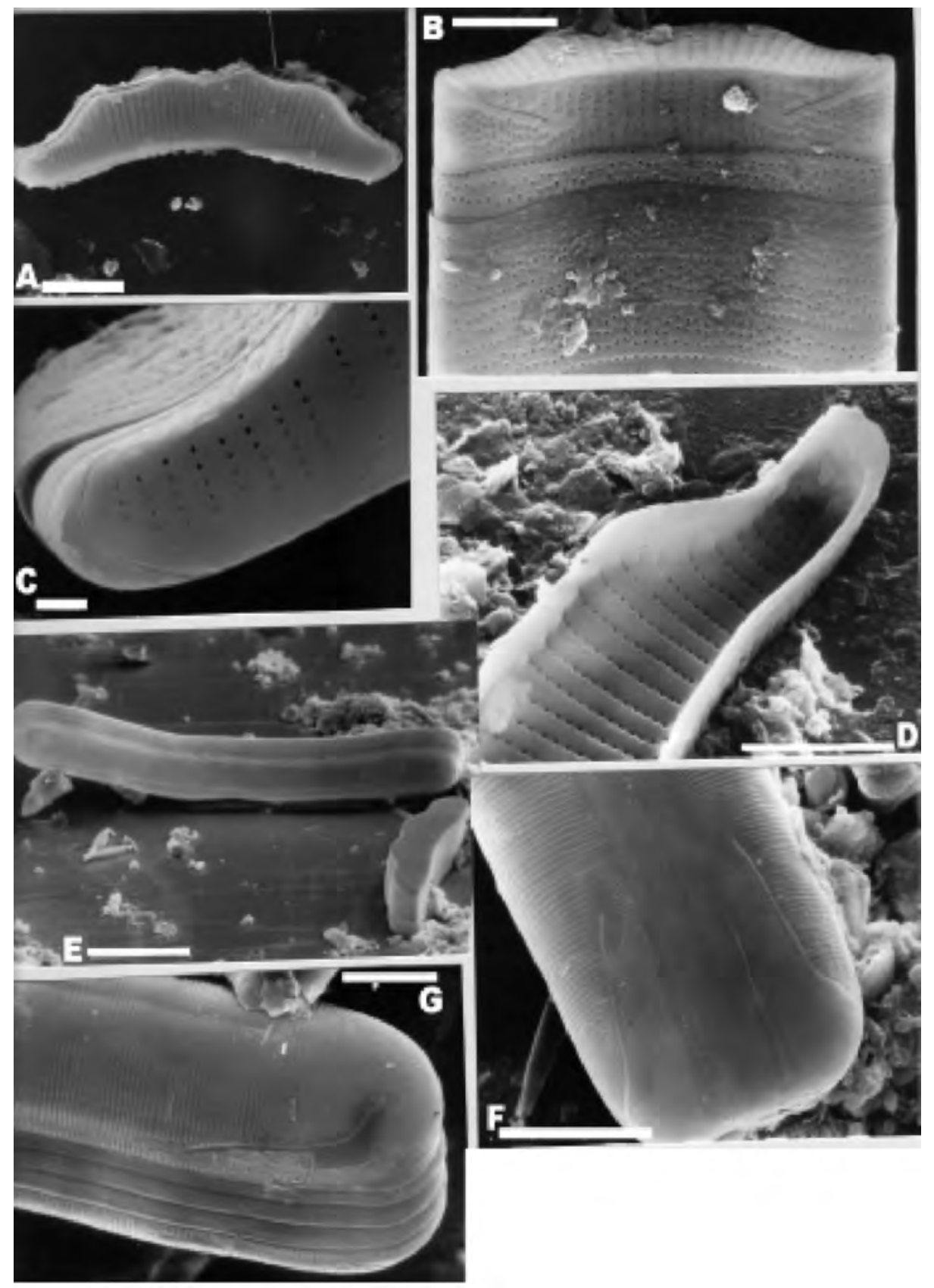

Figure 1. SEM. Scale bars: $1 \mu \mathrm{m}$ : C; $5 \mu \mathrm{m}$ : B, D, F; $10 \mu \mathrm{m}$ : A, E, G.

A-D Eunotia camelus. A: external valve view. B: frustule in girdle view, detail of girdle bands. C: external view, detail of raphe and striae. D: internal view, detail of rimoportula and helictoglossa. $\boldsymbol{E}-\boldsymbol{G}$ Eunotia anamargaritae. E: external valve view. F: external view, detail of raphe and girdle bands. G: detail of raphe and girdle bands in external view. 


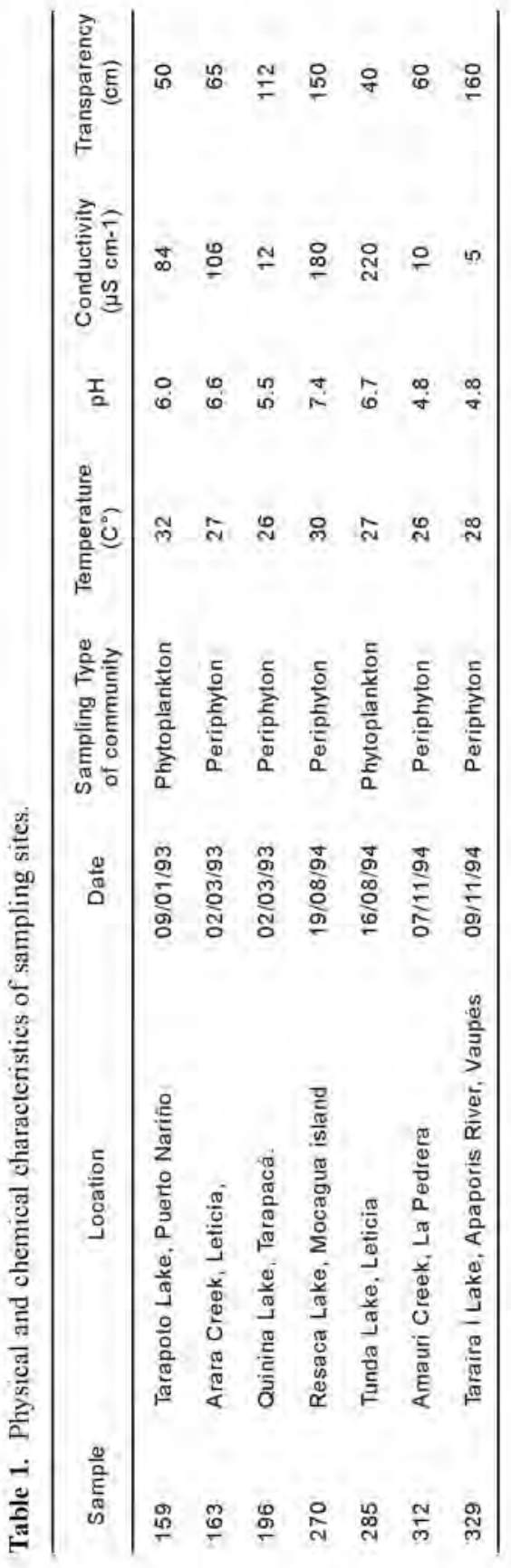

the valve center, interstriae broad. Areolae circular indistinguishable at LM, Raphe lying at the valve face, nearly straight, short and oblique at the mantle, raphe endings not dilated. Helictoglossae small and rimoportula simple, elongated in apical sense. Girdle bands incomplete with a few and distant rows of poroids. Dimensions: length: $17.5-52 \mu \mathrm{m}$; breadth: 5$8 \mu \mathrm{m}$; striae in $10 \mu \mathrm{m}$ : $9-13$ (valve face) and 20 (mantle).

Studied material: samples 159 , 163 and 312 .

Ecology: In the studied area the specimens were collected in habitats with $\mathrm{pH}$ : 4.8-6.6; conductivity: 10-106 $\mu \mathrm{S} . \mathrm{cm}^{-1}$ and transparency: $0.50-0.65 \mathrm{~m}$.

Distribution: cosmopolitan. In Amazonia recorded by Oliveira \& Steintz-Kannan (1992), SouzaMosimann et al. (1997), Metzeltin \& Lange-Bertalot (1998) and Sala et al. (2002).

Observations: in Sala et al. (2002) this species was analyzed only with LM, here we give details of valve morphology.

\section{Eunotia glacialis Meister}

Figs. $2 \mathrm{~A}-\mathrm{C}$

Meister 1912: 85, pl. 10, figs. 2-3.

Valves isopolar, slightly arcuate, ends subcapitated, slightly differentiated from the rest of the valve. Striae uniseriate, parallel; areolae circular, indistinguishable at LM. Raphe visible at LM, crossing the valve face and undulate, oblique with dilated ends at the mantle. Girdle bands with several rows of poroids. Dimensions: length: 93-124 $\mu \mathrm{m}$; breadth: $7-9 \mu \mathrm{m}$; striae in 
$10 \mu \mathrm{m}: 7-12$; areolae in $10 \mu \mathrm{m}: 32$ (only one specimen measured).

Studied material: samples 159, 270 and 285.

Ecology: present in acid waters, usually cool, with low mineral content (Patrick \& Reimer, 1966). Krammer \& Lange-Bertalot (1991) mentioned this species in habitats with low to slightly high electrolytic concentrations. In the studied area the specimens were collected in sites with: $\mathrm{pH}: 6-7.4$; conductivity: $84-220 \mu \mathrm{S} . \mathrm{cm}^{-1}$ and transparency: $0.4-1.5 \mathrm{~m}$.

Distribution: Northern Hemisphere (Krammer \& Lange-Bertalot, 1991). French Guyana (Reichardt, 1995).

Observations: our specimens have a row of little spines at the end of the valve, this characteristic is neither shown in the materials from $\mathrm{Eu}-$ ropean temperate regions studied by Krammer \& Lange-Bertalot (1991) nor in those from South America illustrated in Reichardt (1995). In the Brazilian Amazon Souza- Mossimann et al. (1997) described some specimens as E. cf. glacialis, but our materials differ from them in dimensions and striae density.

Eunotia guianense (Ehrenberg) De Toni Figs. 2 G-H

De Toni 1862: 792.

Bas.: Himantidium guianense Ehrenberg, (1841) 1843. Abh. Königl. Akad. Wiss. Berlin: 417, 2/1, fig. 4.

Syn.: Eunotia pileus var. guianense (Ehrenberg) Reichardt, 1995. Die diat. Ehr. Mat. von Cayenne, Guy. Gall. Germany: 31; pl. 5, figs. 1-8; pl. 24, figs. 9-10.

Valves bilobated, slightly arcuate with subacute ends. Striae uniseriate parallel. Areolae circular, visible with LM. Raphe short, straight in the first half of the valve face and curved on the rest; raphe endings not dilated. Dimensions: 1ength: 42-64 $\mu \mathrm{m}$; breadth at the center: 10-14 $\mu \mathrm{m}$; breadth at the end: $14-20 \mu \mathrm{m}$; central striae in $10 \mu \mathrm{m}$ : 9-12; areolae in 10 $\mu \mathrm{m}: 20-22$.

Studied Material: samples 159 and 163 .

Ecology: in the study area the specimens were collected in two sites with $\mathrm{pH}$ 6-6.6; conductivity: 84-106 $\mu \mathrm{s} . \mathrm{cm}^{-1}$ and transparency: $0.5-0.65 \mathrm{~m}$.

Distribution: Lago Calado, Brazil (Metzeltin \& Lange-Bertalot, 1998), Cayenne (Reichardt, 1995) and Colombian Amazon (Sala et al., 2002).

Observations: in the nomenclatural aspects we followed Metzeltin \& Lange-Bertalot (1998). This species was illustrated in Sala et al. (2002) only with LM (as E. pileus var. guianense), here we give details of fine valve morphology.

\section{Eunotia naegelii Migula} Figs. 3 A-B

Migula 1907: 203, fig. 140: 1-6. Valves isopolar, arcuate, ends subcapitated slightly curved to the dorsal side. Striae uniseriate, parallel, slightly radial at the poles, interstriae wide. Areolae circular, not visible with LM. Raphe fissure curved back towards the center of the valve; raphe endings expanded. Rimoportula small. Girdle bands with one row of poroids. 
Dimensions: length: $38-152 \mu \mathrm{m}$; breadth: $3-5 \mu \mathrm{m}$; striae in $10 \mu \mathrm{m}$ : $16-$ 20; areolae in $10 \mu \mathrm{m}$ : 47-57.

Studied material: samples 159 , 163 and 196.

Ecology: present in acid water with low mineral content (Patrick \& Reimer, 1966). In the studied area the specimens were collected in habitats with: $\mathrm{pH}$ : 5.5-6.6; conductivity: 12$106 \mu \mathrm{S} . \mathrm{cm}^{-1}$ and transparency: $0.5-$ $1.12 \mathrm{~m}$.

Distribution: cosmopolitan (Krammer \& Lange-Bertalot, 1991). This is the first mention of the species in the Amazonian region.

\section{Eunotia cf. paludosa Grunow Figs. 2 D-F}

Grunow 1862: 336, pl. 6, fig. 10.

Valve isopolar, slightly arcuate, dorsal and ventral sides parallel. Ends subcapitated. Striae parallel along the valve face, radial at one pole. Areolae circular, not visible with LM. Raphe oblique at the valve face, raphe endings slightly expanded. Helictoglossae conspicuous, rimoportula small, on the mantle at the end of the valve. Girdle bands with several rows of poroids. Dimensions: length: 41-59 $\mu \mathrm{m}$; breadth: $4-7 \mu \mathrm{m}$; striae in $10 \mu \mathrm{m}$ : $15-$ 20; areolae in $10 \mu \mathrm{m}$ : 34-45.

Studied material: samples 159 , 312 and 329.

Ecology: often found associated to mosses in acid waters of low mineral content, also in bogs and small streams (Patrick \& Reimer, 1966). In the study area the specimens were collected in habitats with: $\mathrm{pH}$ : 4.8-6, conductivity: 5-84 $\mu$ S.cm ${ }^{-1}$, transparency:
$0.50-1.6 \mathrm{~m}$.

Distribution: cosmopolitan (Krammer \& Lange-Bertalot, 1991).

Observations: Metzeltin \& LangeBertalot (1998) transferred materials from Demerara River described in Hustedt (1930) as E. paludosa Grunow to E. distinguenda but our materials differ from the specimens illustrated by Metzeltin \& Lange-Bertalot (1998) in dimensions and valve outline and fine valve morphology. In addition, the specimens studied by us are wider and have a less number of striae in $10 \mu \mathrm{m}$ than those described by other authors, e.g. breadth: 2-3(4) $\mu \mathrm{m}$ and 2-4 $\mu \mathrm{m}$; striae en $10 \mu \mathrm{m}$ : (16) 19-25 (32?) and 20-25 in Krammer \& Lange-Bertalot (1991) and Patrick \& Reimer (1966) respectively.

Eunotia pseudoindica Frenguelli Figs. 3 C-E

Frenguelli, 1941: 307.

Syn.: Eunotia indica Frenguelli 1933. An. Mus. Nac. Hist. Nat., Bs. As.: 453, pl. 9, figs. 11-13.

Valves isopolar, ventral margin straight and dorsal margin convex; endings elongated and attenuated at the poles, well differentiated from the rest of the valve. Raphe visible with LM. Striae uniseriate, parallel alongside the valve and radial at the poles alternating with shorter striae at the dorsal margin. Areolae circular, visible with LM. Rimoportula at the end of the valve in oblique position. Dimensions: length: $50-52 \mu \mathrm{m}$; breadth: 9,6$10 \mu \mathrm{m}$; striae in $10 \mu \mathrm{m}$ : 10-11; areolae in $10 \mu \mathrm{m}: 20-28$.

Studied material: sample 159 .

Ecology: in the literature there is 

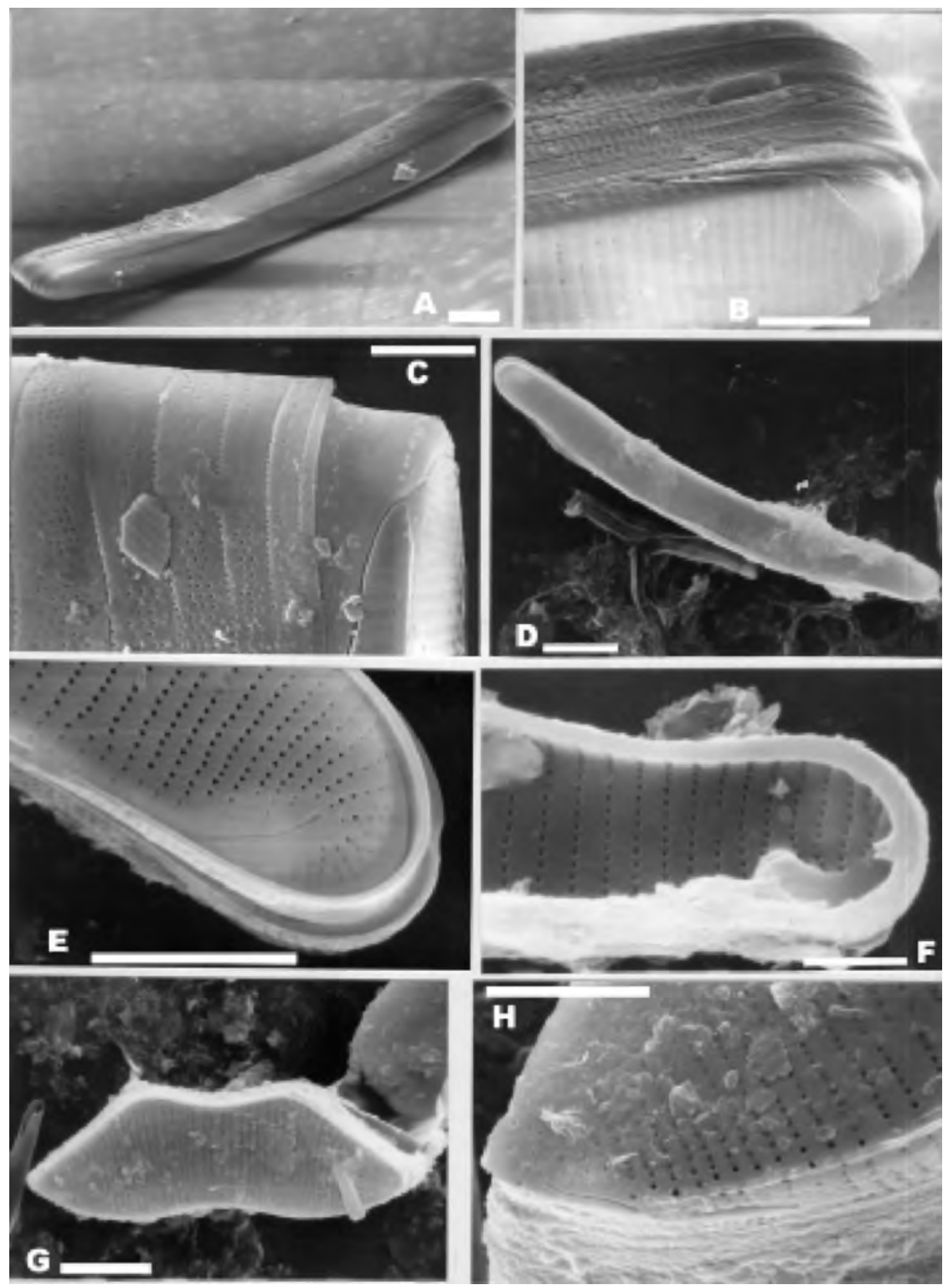

Figure 2. SEM. Scale bars: $5 \mu \mathrm{m}$ : B-C, E-F, H; $10 \mu \mathrm{m}$ : A, D, G.

A-C Eunotia glacialis. A: general aspect of the frustule. B: external valve view, detail of the striae and raphe. C: external valve view, detail of girdle bands and raphe. D-F: Eunotia cf. paludosa. D: external valve view. E: detail of raphe and striae in external valve view. F: Internal view, detail of rimoportula, helictoglossa and striae. G-H: Eunotia guianense. G: external valve view. $\mathbf{H}$ : external view, detail of raphe and striae. 
no information. In the study area the specimens were collected in Tarapoto Lake (pH: 6 ; conductivity: $84 \mu \mathrm{S} . \mathrm{cm}^{-}$ ${ }^{1}$ and transparency: $0.5 \mathrm{~m}$ ).

Distribution: present in tropical and subtropical regions from South America. This is the first mention for the species in the Amazon region.

Observations: our materials were determined on the basis of characters visible with LM following the descriptions given in Frenguelli (1933).

Eunotia transfuga Metzeltin \& Lange-Bertalot Figs. 3 F-H

Metzeltin \& Lange-Bertalot 1998: 84, figs. 9:1-3; fig. 8: 5 .

Valves isopolar, slightly arcuate with subcapitate apices. Striae uniseriate, parallel and strongly radial at the ends; interrupted by a slightly visible axial area in the ventral margin. At the valve face and mantle junction there is a row of conspicuous spines. Raphe on the mantle slightly developed at valve face. Girdle bands with seve-ral rows of poroids. Dimensions: length: 136-159 $\mu \mathrm{m}$, breadth: 8$9 \mu \mathrm{m}$, striae in $10 \mu \mathrm{m}: 17-18$, areolae in $10 \mu \mathrm{m}: 28-32$, spines in $10 \mu \mathrm{m}: 6$.

Studied material: samples 163 and 312 .

Ecology: we did not find information in the literature. In the studied area the specimens were collected in habitats with: $\mathrm{pH}$ : 4.8-6.6, conductivity: 10-160 $\mu \mathrm{s} . \mathrm{cm}^{-1}$, transparency: $0.6-0.65 \mathrm{~m}$.

Distribution: this species could be endemic of the Amazon region as up to now it was found only in the Brazilian Amazon (Metzeltin \& Lange-Bertalot, 1998).
Observations: in the literature the specimens are longer than those studied by us. This species is close related with E. rabenhorstiana var. rabenhorstiana. Metzeltin \& Lange-Bertalot (1998) separated these species taking into account differences in pole morphology (more dilated in E transfuga)

Eunotia triodon Ehrenberg Figs. 4 A-C

Ehrenberg 1837: 45.

Valves with the ventral margin concave and dorsal one with three undulations. Rounded ends differentiated from the rest of the valve. Striae uniseriate, slightly sunken, parallel in the whole valve with some shorter striae between them. Areolae circular. Raphe oblique lying mostly at the mantle, raphe endings slightly curved. Girdle bands with several rows of poroids. Dimensions: length: $37 \mu \mathrm{m}$; breadth: $10 \mu \mathrm{m}$ (center); striae in 10 $\mu \mathrm{m}$ : 13; areolae in $10 \mu \mathrm{m}$ : 35 (only one specimen measured).

Studied material: sample 329.

Ecology: prefer oligotrophic to somewhat acid water (Patrick \& Reimer, 1966). In the study area collected in a lake with low $\mathrm{pH}(4.8)$ and extremely low conductivity $\left(5 \mu \mathrm{S} . \mathrm{cm}^{-1}\right)$.

Distribution: Alpine regions of Northern Europe (Krammer \& LangeBertalot, 1991). This is the first mention of the species in a tropical region. Mentioned in the Colombian Andes by West (1914).

Observations: our materials were determined on the basis of LM characters as it was not previously studied with SEM. The studied specimens are 


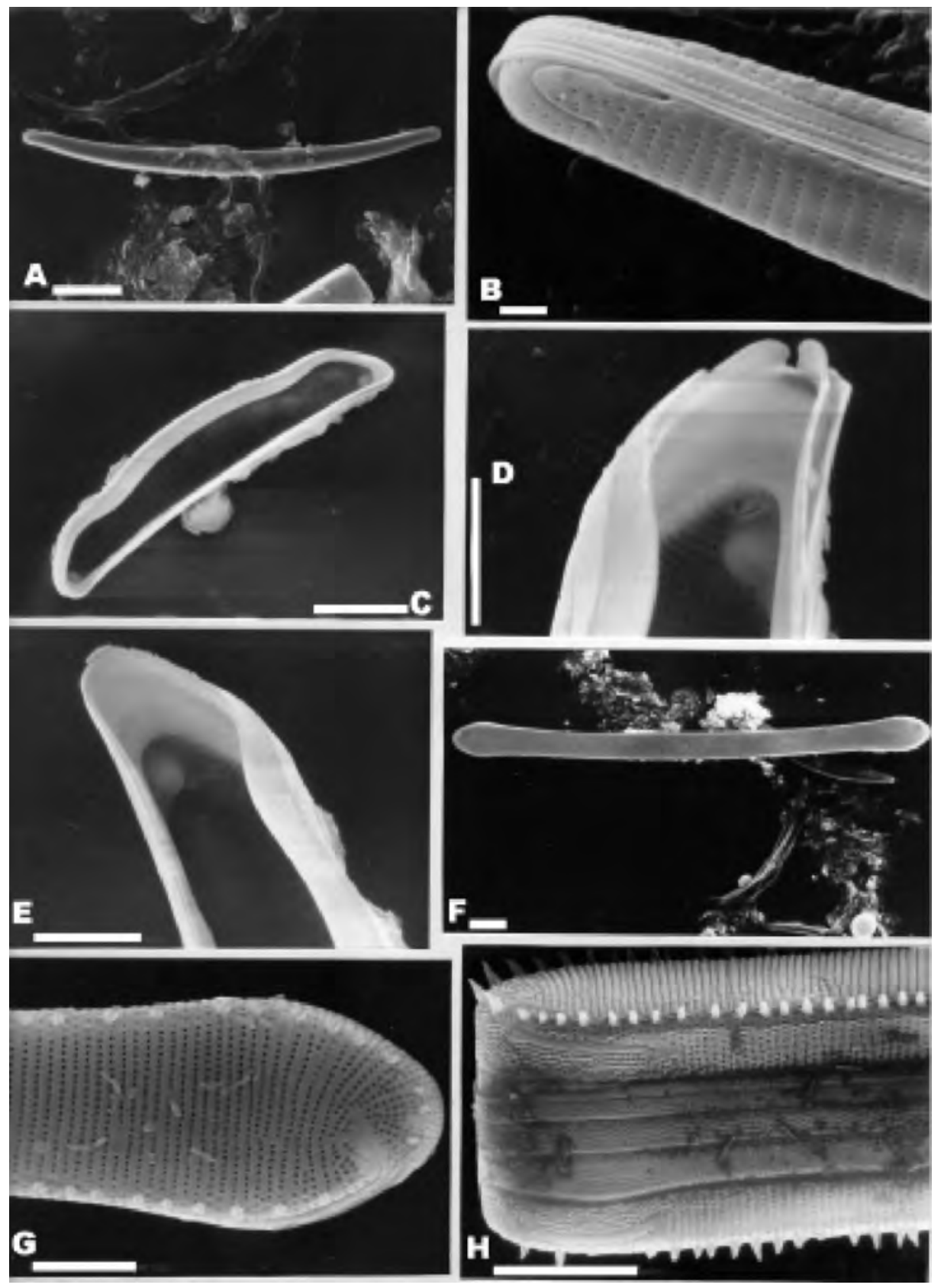

Figure 3. SEM. Scale bars: $1 \mu \mathrm{m}$ : B, E; $5 \mu \mathrm{m}$ : D, G; $10 \mu \mathrm{m}$ : A, C, F, H.

A-B Eunotia naegelli. A: external valve view. B: detail of striae, raphe and girdle bands. C-E Eunotia pseudoindica. C: internal valve view. D: internal view, detail of rimoportula and helictoglossa. $\mathbf{E}$ : internal view of the pole without rimoportula, detail of the helictoglossa. FH: Eunotia transfiga. F: external valve view. $\mathbf{G}$ : detail of the raphe and striae in external view. $\mathbf{H}$ : frustule in external view, detail of the girdle bands, striae, raphe and spines. 
similar in valve outline to E. trigibba Hustedt, but differ from the specimens of this species illustrated in Metzeltin \& Lange- Bertalot (1998), in raphe morphology. A study with SEM of the type material of these two taxa is necessary to clarify identification problems.

\section{Eunotia zygodon var. compacta} Hustedt Figs. 4 D-F

Hustedt 1913 in Schmidt et al. 1874-1959: pl. 287, fig. 8.

Valves isopolar with ventral margins slightly concave and dorsal ones with two undulations and ends differentiated from the rest of the valve. Raphe long, well developed on the mantle, slightly curved on the valve face. Striae uniseriate, parallel, radial at the poles alternating on the dorsal margin with short striae between them. Areolae circular, visible with LM. Rimoportula on the dorsal side of the poles. Helictoglossae differentiated, with a big hyaline area. Girdle bands with several rows of poroids Dimensions: length: $68-108 \mu \mathrm{m}$, breadth: 14$17 \mu \mathrm{m}$, striae in $10 \mu \mathrm{m}: 12-18$, areolae in $10 \mu \mathrm{m}: 25-28$.

Studied material: sample 312 .

Ecology: we did not find information in the literature. In the study area the specimens were collected in Amauri Creek with $\mathrm{pH} 4.8$, conductivity: 10 $\mu \mathrm{S} . \mathrm{cm}^{-1}$ and transparency: $0.60 \mathrm{~m}$.

Distribution: neotropical (Schmidt et al., 1874-1959). This is the first mention of this species in the Amazon region.

Observations: the identification of our materials was based on LM characters since the only illustrations of the species are in Schmidt et al.
(1874-1959) and Simonsen (1987)

\section{Discussion and Conclusions}

The analysis of these samples showed that the genus Eunotia is very well represented in this region.

Besides the ten taxa included in this paper, another eight taxa were previously reported in the study area in Sala et al. (2002).

Eunotia glacialis, E. transfuga, E. paludosa, E. pseudoindica, E. naegelli and E. zygodon var. compacta were recorded for the first time in Colombia. All of these species except $E$. transfuga were also mentioned for the first time for the Amazon region. Eunotia triodon has been collected from the Colombian Andes (West, 1914) but is listed here for the first time in South American lowland tropical regions. Our results and previous information suggest that, $E$. anamargaritae, E. guianense, E. pseudoindica, E. transfuga and $E$. zygodon var. compacta are present only in neotropical habitats while E. camelus, E. glacialis, E. naegelli, E. paludosa and E. triodon are cosmopolitan.

All the studied taxa were analyzed with SEM. The fine valve morphology of $E$. anamargaritae; E. pseudoindica, E. triodon and E. zydodon var. compacta is described for the first time. In the case of the other species, the comparison of our results with observations in the literature showed little differences in dimensions and details of valve morphology. Our specimens of E. camelus differ from others in that the raphe fissures do not reach the dorsal margin. Our specimens of $E$. glacialis differ from those described by Krammer \& Lange 

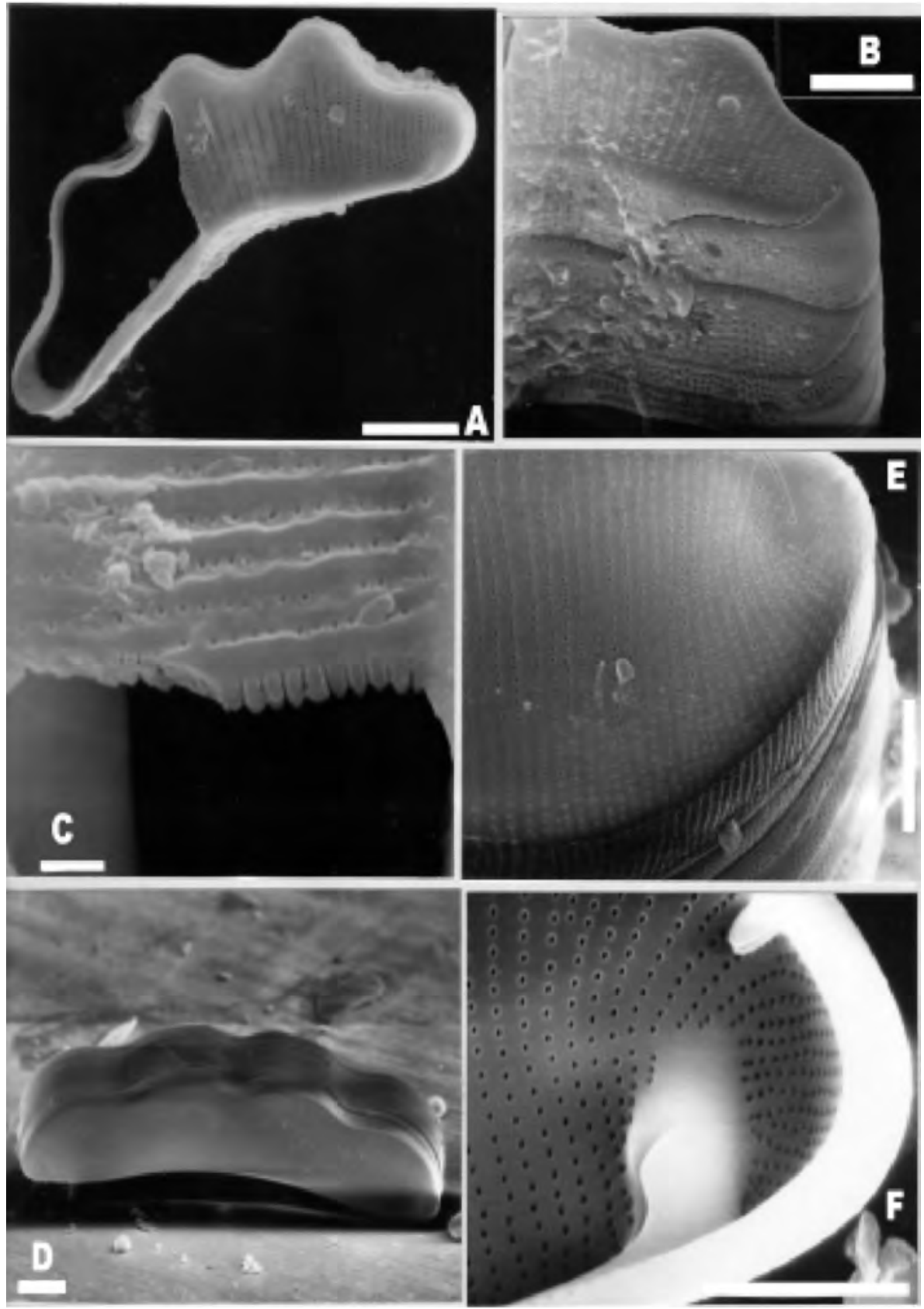

Figure 4. SEM. Scale bars: $1 \mu \mathrm{m}$ : C, E; $5 \mu \mathrm{m}$ : B, F: $10 \mu \mathrm{m}$ : A, D.

A-C Eunotia triodon: A: external valve view. B: detail of raphe and girdle bands in external view. C: broken valve, detail of striae and areolae. D-F: Eunotia zygodon var. compacta: D: general aspect of a frustule. $\mathbf{E}$ : detail of striae and raphe in external view. F: internal valve view, detail of the rimoportula and helictoglossa. 
Bertalot (1991) in the presence of a row of little spines at the valve, ends and our specimens of $E$. cf. paludosa are wider and have more striae in $10 \mu \mathrm{m}$ than those described in Patrick \& Reimer (1966) and Krammer \& Lange Bertalot (1991). Nevertheless we think that these differences are not enough to consider our material as another species.

The study area is characterised by low to neutral $\mathrm{pH}$, moderate conductivity with sometimes extremely low values, low transparency and high temperature. The ecological characteristics given in the literature for the majority of the studied taxa agree with our observations. There were no ecological data for three species: E. pseudoindica was found in a lake with low $\mathrm{pH}$ (6) and low conductivity $\left(84 \mu \mathrm{S} . \mathrm{cm}^{-1}\right)$. E. transfuga was collected in two waterbodies with low $\mathrm{pH}$ (4.8-6.6) and extremely low to moderate conductivity $\left(10-106 \mu \mathrm{S} . \mathrm{cm}^{-1}\right)$. Finally E. zygodon var. compacta was collected in Amauri Creek, which has low $\mathrm{pH}$ (4.8) and extremely low conductivity $\left(10 \mu \mathrm{S} . \mathrm{cm}^{-1}\right)$.

\section{Acknowledgements}

This is study was supported by the Universidad de La Plata, Argentina; Universidad Nacional de Colombia, Leticia; Instituto Amazónico de Investigaciones Científicas - Sinchi and COLCIENCIAS. T. Deffler assisted the English translation. M. E. Morales elaborated the final drawings.

\section{Literature cited}

De Toni, G. B. (1891-1894). Sylloge algarum omnium hucusque cognitarum vol. II; Bacillarieae. Sectio I, Raphideae: 1-490 (1891); Sectio II; Pseudoraphideae: 491-
817.

Duque, S.R. 1998. Estudio de humedales en la Amazonia colombiana. En: E. Guerrero (ed.). Una aproximación a los humedales en Colombia. Unión Internacional para la Conservación de la Naturaleza (UICN-sur) \& Fondo FEN Colombia. Santa Fe de Bogotá, Colombia: 73-91.

Duque, S.R.; Ruiz, J.E.; Gómez, J.; Roessler, E. 1997. Limnología. In: IGAC (ed.). Zonificación ambiental para el plan modelo Colombo - Brasilero (Eje Apaporis - Tabatinga: PAT). Editorial Linotipia. Santafé de Bogotá. 71-134.

Ehrenberg, C.G. 1837. Über ein aus fossilen Infusorien bestehendes, $1832 \mathrm{zu}$ Brot verbacknes Bergmehl von den Grenzen Lapplands in Schweden. Bericht über die zur Bekanntmachung geeigneten Verhandlungen der Königl. Preuss. Akademie der Wissenschaften zu Berlin, S. 43-45.

Ehrenberg, C.G. 1841 (1843). Verbreitung und Einfluss des mikroskopischen Lebens in Süd - und Nord-Amerika. Abhandlungen der Königlichen Akademie der Wissenschaften zu Berlin,S.139-144.

Frenguelli, J. 1933. VII Contribución al conocimiento de las diatomeas argentinas. Diatomeas de la Región de los Esteros del Yberá. Anales del Museo Nacional de Historia Natural "Bernardino Rivadavia", Bs. As. 365-475.

Frenguelli, J. 1941. XVI Contribución al conocimiento de las diatomeas argentinas. Diatomeas del Río de la Plata. Revista Museo La Plata (n. s.) III, Sec. Botánica: 213-334.

Furch, K.; Klinge, H. 1978. Towards a regional characterization of the biogeochemistry of alkali and carth alkali metals in nothern South America. Acta Cient. Venezolana, 29: $434-444$

Furch, K.; Klinge, H. 1982. Unusual chemistry of natural waters from the Amazon region. Acta Cient. Venezolana, 33: 269-273

Gaul, U; Geissler, U.; Henderson, M.; Mahoney, R.; Reimer, Ch.W. 1993. Bibliography on the fine-structure of diatom 
frustules (Bacillariophyceae). Proceedings of the Academy of Natural Sciences of Philadelphia 144: 69-238.

Gibbs, R.J. 1970. Mechanisms controlling world water chemistry. Science, 170: 1088-1090

Grunow, A. 1862. Die österreichischen Diatomaceen nebst Anschluss einiger neuen Arten von andern Lokälitaten und einer kritischen Übersicht der bisher bekannten Gattungen und Arten. Erste Folge. Epithemieae, Meridioneae, Diatomeae, Eutopyleae, Surirellaeae, Amphipleureae: Zweite Folge. Familie Nitzchieae. Verhandlungen der kaiserlichköniglichen zoologisch-botanischen Gesellschaft in Wien, Bd. 12, S. 315-472, 545-585, 6 Taf.

Hasle, G.R.; Fryxell, G.A. 1970. Diatoms: cleaning and mounting for light and electron microscopy. Trans. Amer. Micros. Soc. 89: 469-474.

Hustedt, F. 1930. Bacillariophyta (Diatomeae). In: A. Pascher. (ed.). Die Süsswasser Flora Mittleuropas. Heft. 10, 466 S. 875 fig. Auflage. Gustav Fischer, Jena.

Hustedt, F. 1965. Neue und wenig bekannte Diatomeen: IX. Süsswaserdiatomeen aus Brasilien, inbesondre des Amazonasgebietes. Inter. Rev. Ges.Hydrobiol. 50: 391-410.

Krammer, K.; Lange-Bertalot, H. 1991. Süsswasserflora von Mitteleuropa. Bacillariophyceae, Teil 3: Centrales, Fragilariaceae, Eunotiaceae. Jena. Gustav Fischer Verlag. 576 pp., 166 pl.

Mayama, S. 1992. Morphology of Eunotia multiplastidica sp. nov. (Bacillariophyceae) examined throughout the life cycle. The Korean Journal of Phycology 7 (1): 45-54.

Mayama, S.; Kobayasi, H. 1991. Observations of Eunotia arcus Ehr., type species of the genus Eunotia (Bacillariophyceae). The Japanese Society of Phycology 39 (2): 131-141.

Meister, F. 1912. Die Kieselalgen der Schweiz. Beiträge zur Kryptogamenflora der Schweiz. Band IV, Heft 1, 254 S., 48 Taf. Wyss, Bern.
Metzeltin, D.; Lange-Bertalot, H. 1998. Tropical diatoms of South America I. In: LangeBertalot (Ed.). Iconographia Diatomologica. Vol. 5. H. Koeltz Scientific Books, Germany. $695 \mathrm{pp}$.

Migula, W. 1907. Kryptogamen- Flora von Deutschland, Deutsch-Österreich und der Schweiz in Anschluss Aspergillus nidulans Thome's Flora von Deutschland, Österreich und der Schweiz. (Band VI, Kryptogamen- Flora), Band II, Algen, Teil 1, Cyanophyceae, Diatomaceae, Chlorophyceae, S. 1-918, 43 Taf. Friedrich von Zeuzchwitz, Gera.

Oliveira, P. E.; Steintz-Kannan, M. 1992. The diatom flora (Bacillariophyceae) of the Cuyabeno Faunistic Reserve, Equadorian Amazonia. Nova Hedwigia 54 (3-4): 515 552.

Patrick, R.; Reimer, Ch.W.. 1966. The diatom of the United States exclusive of Alaska and Hawaii. Vol 1. Monographs of The Academy of Natural Sciences of Philadelphia $\mathrm{N}^{\circ} 13.688 \mathrm{pp} ., 64 \mathrm{pl}$.

Reichardt, E. 1995. Die Diatomeen (Bacillariophyceae) in Ehrenberg's Material von Cayenne, Guyana Gallica (1843). Koeltz Scientific Books. Germany. 107 pp

Round, F. E.; Crawford, R.M.; Mann., D.G 1990. The diatoms. Biology and morphology of the genera. Cambridge University Press. $747 \mathrm{pp}$.

Sala, S. E.; Duque, S.R.; Nuñez-Avellaneda, M.; Lamaro, A.A. 1999. Nuevos registros de diatomeas (Bacillariophyceae) de la Amazonia Colombiana. Caldasia.21 (1): 26-37.

Sala, S. E.; Duque, S.R.; Nuñez-Avellaneda, M.; Lamaro, A.A. 2002. Diatoms from the Colombian Amazon. Cryptogamie, Algologie. 23 (1): 75-99.

Schmitd A.; Schmidt, M.; Fricke, F.; Heiden, H.; Müller, O.; Hustedt, H. 1874-1959. Atlas der Diatomaceen Kunde, R. Reisland, Leipzig. $472 \mathrm{pl}$.

Simonsen R. 1987. Atlas and catalogue of the diatom types of Friedrich Hustedt. Vol 1. 525 pp. Catalogue. J. Cramer. Berlin. 
Stuttgart.

Souza-Mosimann R. M.; Tavares, A.S.; Freitas, V.P. 1997. Contribuiçâo ao conhecimento da diatomoflórula do conteúdo estomacal de algumas espécies de peixes da Amazônia.I. Myleus sp. (pacu) do lago do Prato, AM., Brasil. Acta Amazonica 27 (1): 9-26.

Uherkovich, G. 1976. Algen aus den Flüssen Rio Negro und Tapajós. Amazoniana 5: 465-515.

Uherkovich, G.; Franken, M. 1980. Aufwuchsalgen aus zentralamazonischen Regenwaldbächen. Amazoniana 7 (1): 4979.

Uherkovich, G.; Rai, H. 1979. Algen aus dem Rio Negro und seinen Nebenflüssen. Amazoniana. 6 (4): 611-638.

Uherkovich, G.; Schmidt, G.W. 1974. Phytoplanktontaxa in dem zentralamazonischen Schwemmlandsee Lago do Castanho. Amazoniana 5: 243-283.

Van Landingham, S. 1969. Catalogue of the fossil and recent genera and species of Diatoms and their synonyms 3: 10871756. J. Cramer. Germany.

West, B. S. 1914. A contribution to our knowledge of freshwater algae of Colombia. In: Furhmann \& Mayor (Eds.). Vogage d' exploration scientifique in Colombie: 1013-1051.

Aceito para publicação em 12/08/2002. 
